\title{
Sustainable mobility in Cyprus: the city of Limassol
}

\author{
S. Gerasimou ${ }^{1} \&$ M. Georgoudis ${ }^{2}$ \\ ${ }^{I}$ Department of Humanities, Social Sciences and Law, \\ Faculty of Applied Mathematics and Physics, \\ National Technical University of Athens, Greece \\ ${ }^{2}$ Department of Civil Engineering and Geomatics, \\ Faculty of Engineering and Technology, \\ Cyprus University of Technology, Cyprus
}

\begin{abstract}
The city is the main nucleus of social life which creates civilization and reflects the values and traditions of society. According to Plato the ideal city should be built 10 miles from the shore on a rough soil with a rich inner land. The main characteristic of the town could be resumed in the prevalence of public interest on individual ones, while virtue was the most important value of living together. The city of Limassol, located on the southern coast of Cyprus, is the second biggest city on the island and one of the most important maritime, commercial, tourism and service centres in the wider area. Thus, the port of Limassol mainly due to its position, i.e. the last port before the Suez Canal, is considered a junction port between Europe, Asia and the Middle East. After an analysis on town planning principles, the paper focuses on the concepts of sustainable mobility and sustainable city. Next we examine the 'Olympic Shore' project of the city of Limassol as a successful example implementing sustainability. Besides, the case study in question should be considered as a model of a modern sustainable and environment-friendly intervention, which has played a key role in designing other similar projects on the island of Cyprus.

Keywords: sustainable mobility, walkability, urban renaissance, Limassol, Cyprus.
\end{abstract}




\section{Introduction}

The city is the main nuclear of social life which creates civilization and reflects the values and traditions of society. During the classical era, Greek philosophers had expressed their ideas on city planning, which reflected the ideals of democracy on urban space. According to Plato the ideal city should be built 10 miles from the shore on a rough soil with a rich inner land. The main characteristic of the city could be resumed in the prevalence of public interest on individual ones, while virtue was the most important value of living together (Hatzopoulou [1]). Following the same ideas Aristotle supported that social life should be guided by the principles of justice and political virtue; therefore the city had to adopt a middle size in harmony with its population (Aristotle [2]). These classical perceptions reflect a holistic approach of the city and the afferent policies.

On the contrary, in contemporary western society emphasis has been put mainly on economic development through a utilitarian use of the land. This approach has proved to be quite profitable for industrial countries, for it has contributed considerably to the rise of their GNP as well as the average per capita income. However, in the seventies amid the two first energy crises (1973, 1979) environmental concerns made their appearance obliging western nations to reconsider their development policies. Ecology, cultural heritage and quality of life were seen as promising alternatives to the so far economic policies which had deteriorated the natural and built environment. From then on the protection of the environment (natural, built, cultural), has become one of the main pillars of public policies.

Within this context, in 1972 a group of MIT scientists, after an instruction from the team Club of Rome, published an essay with the name "The limits to growth". In this essay, five variables were examined in the original computer model. The assumptions of this essay were that: a. exponential growth accurately described their patterns of increase and b. that the ability of technology to increase the availability of resources grows only linearly. These variables were: world population, industrialisation, pollution, food production and resource depletion. The authors intended to explore the possibility of a sustainable feedback pattern that would be achieved by altering growth trends among these five variables [3].

In the mid eighties the protection of the environment, at first in contradiction with economic development, soon reached a compromise with the latter within the principle of sustainability as it was defined in the Brundtland report (1987). According to the Brundtland Commission "sustainable development is the development that meets the needs of the present without compromising the ability of future generations to meet their own needs". Thus, it comprises two key elements:

- the concept of needs, in particular the essential needs of the world's poor, to which overriding priority should be given; and

- the idea of limitations imposed by the state of technology and social organisation on the ability of the environment to meet present and future needs [4]. 
So, sustainable development puts forward a new development model combining economic growth, the protection of the environment and social cohesion. The combined approach of these three pillars could be apprehended as a reintroduction of a holistic policy closer to the classical philosophy.

In European level, the goal of sustainable development has influenced policy makers since it has become a key element in the EU political agenda. Thus, in 2001 in Göteborg the European Council discussed a strategy for sustainable development, "A Sustainable Europe for a better world: A European Strategy for Sustainable Development", proposed by the European Commission. The strategy put forward measures to deal with threats to the quality of life, focusing on issues such as climate change, poverty and emerging health threats [5]. Since then, various texts have been adopted. EU sustainable development strategy was updated in 2006 to tackle shortcomings and take into account new challenges. Moreover, since sustainable development is closely tied to climate change and energy policy, the revised plan stresses the importance of education, research and public funding to achieve sustainable production and consumption patterns [6].

Furthermore, sustainability has become one of the main pillars of European regional and city policies. In this context the importance of sustainable mobility within European cities has risen and sustainable mobility has become one of the main targets of urban policies. Therefore, EU policy-makers are trying to rationalise transport activity and develop policies of sustainable mobility. The Commission set out a strategy on sustainability in the transport sector in its 2001 White Paper on Transport Policy. The strategy focuses predominantly on balancing the different modes of transport and harmonising legislation within specific sectors, but also on enhancing transport safety [7].

\section{Sustainable mobility and sustainable city}

\subsection{Sustainable mobility}

Like sustainable development, sustainable mobility has three dimensions: environmental, economic, and social one [8]. The environmental aspect refers to air pollution and noise caused by transport activities, water contamination and natural resources consumption, the economic one is related to regional and urban economy, transports cost, competitiveness and subsidies, while the social aspect concerns health, equality, justice of opportunities and the right of mobility.

More specifically, sustainable mobility appeals to public transport and to physical types of movement such as pedestrians and bicycles. For the usage of physical types of movement, several improvements are required to take place such as:
- Larger pavements
- Several crossings in the roads
- Various green fields
- Improvement of architecture 


\subsection{Sustainable city}

The implementation of sustainability rules in the city imported the concept of sustainable city which depends on the shape, the operation, the social and political identity of the city. The role of cities is indispensable in sustainable development. Thus, the city can have a large building density or small townssatellites around it. Under this framework, the two most common proposals are compact cities and multicentre cities.

In recent years city planners and developers have looked towards designing a more compact city in order to achieve a better sustainable urban form. Policies of urban compaction involve the promotion of urban regeneration, higher densities, mixed-use development, the promotion of public transport and the concentration of urban development at public transport nodes. There are many perceived benefits of the compact city which include less car dependency and consequently lower emissions, reduced energy consumption, better public transport services and a higher quality of life, for sustainable development relies upon the combination of economic, social and environmental elements (Newman and Kenworthy [9]). This model applies mainly to European towns and cities with a historic nuclear since it can lead to the revival of the historical and commercial part encouraging simultaneously housing uses.

On the other hand, multicentre cities apply to cases of cities where compact city is not possible. This is the case of wider metropolitan areas where sustainability could be achieved with the development usually of more than one centre and on the solid development around them fostering high density and mixed uses [10].

\section{Bringing sustainable mobility to life: Olympic shore, Limassol, Cyprus}

\subsection{Historical evolution of the city of Limassol}

The city of Limassol is located on the southern coast of Cyprus between the ancient cities of Amathus and Curium. It has a history of more than 4 millennia. According to archaeological findings (i.e. graves dating back to 2.000 B.C. and others to the 8th and 4th century B.C.), it is believed that in ancient times in the location of the actual city there used to be a small settlement which did not manage to develop and flourish. During the Roman Empire the bishop of Theodossiani, Sotir, as well as the bishops of Amathus and Arsinoe were involved in the foundation of the city (Holy Synod 451 B.C.). Later in the $10^{\text {th }}$ century, the town was known under the name of Nemessos and the Byzantine emperor Constantine VII Porphyrogenitus, "the Purple-born" refers to the town by this name [11].

1191 A.D. marks the end of the Byzantine dominion of Cyprus. The island became a target of the crusaders and Richard the Lionhearted landed in Limassol on the 1st of June 1191, where he celebrated his marriage with Berengaria of Navarre [12]. Richard the Lionhearted destroyed the city of 
Amathus and the residents were transferred to Limassol, which was probably built after Amathus had been ruined. One year later, Richard sold Cyprus to the Knights Templar, who imposed a large amount of tax on the island against the will of the locals.

Next, the island was sold to Guy De Luisignan, a Poitevin knight, son of Hugh VIII of the prominent Lusignan dynasty. For the next 3 centuries (11921489) Limassol enjoyed a remarkable prosperity and especially in the $13^{\text {th }}$ century a large number of merchants settled down in the city leading to the financial welfare of its inhabitants. Its harbor as a center of transportation and commerce contributed greatly to the financial and cultural development.

Due mainly to its economic and geostrategic advantages the city, following the fate of the entire island, has known hitherto a series of conquests. Thus, in 1228 Limassol was conquered by the King of Germany, Frederick II, and in 1424 by Mamelukes of Egypt who burnt the city. In the year 1489 Cyprus was sold to the town of Venice by the Cypriot Queen Catherine Cornaro and remained under Venetian domination until 1570, when the Ottomans occupied the island. Moreover, Venetians were only interested in receiving taxes and in exploiting the country's sources. They destroyed the Castle of Limassol. All the inhabitants of Cyprus were enslaved and obliged to pay a tribute of $1 / 3$ of their income, whether this was part of their products of the land, e.g. wheat, wine, oil, or animals or of any other product.

Under the Ottoman rule (1489-1878) Limassol like the island of Cyprus in general faced a general decline; Greeks and Turks used to live in separate locations.

In 1878, as the result of the Cyprus Convention, the United Kingdom took over the government of Cyprus as a protectorate from the Ottoman Empire. The first British governor of Limassol, kernel Warren, showed a lot of interest in Limassol and since his first days a lot of new public works were built to enhance the quality of life; i.e. roads, trees were planted, platforms at the port were constructed and the animals were banned from the city centre. It should be underlined that since the first years of the British rule, the first post office, the first telegraph office and the first hospital started to operate. In 1880 lanterns for the lighting of the central areas were installed, while in 1912 they were replaced by electricity. In the end of 19th century the very first hotels began to operate, among which were "Europe" and "Amathus". Furthermore, during this period the number of inhabitants passed from 6,131 in 1881 to 43,593 in 1960 (around 37,478 Greeks and 6,115 Turks). Meanwhile, the main occupation of the inhabitants of Limassol was winery and ceramics.

In 1960 the Republic of Cyprus was created and in 1974 Turkey invaded Cyprus and seized the northern third of the island. Consequently, Turkish Cypriots in the south would travel north and Greek Cypriots in the north were forced to move to the south [13]. Hence, the population of Limassol from 50,000 reached 150,000, whilst nowadays the city's population has risen to 161,000 inhabitants. This event and especially the occupation of Famagusta by the Turkish army marked the beginning of tourist and commercial development of the city. Since 1974, a continuous development is taking place, and a lot of 
tourists visit Limassol every year. Besides, Limassol has one of the largest ports in the Mediterranean Sea and because of its position - the last port before Suez canal- it is considered a junction port between Europe, Asia and the Middle East. In the seventies, among the most important public works could be pointed out the embankment of an area $1 \mathrm{~km}$ along the coastline next to the old port, following a study conducted by National Technical University of Athens. The main reason leading to this public work was to secure the port from sea waves which used to cover the road. Moreover, the area has evolved into a recreational zone for city users.

\subsection{The Limassol Olympion Coast: a step towards sustainable mobility}

Olympion Coast is the busiest part of the coastline in Limassol, $2 \mathrm{~km}$ long, from the embankment area (old port) until the Holiday Inn Hotel. The urban renaissance project in question, included in Limassol local center plan and carried out according to a study conducted by the National Technical University of Athens could be considered a successful urban intervention with a direct impact on the improvement of Limassol citizen daily life. The project demanded the collaboration of both the central government (Urban Department) and the municipality of Limassol. It cost 5 million euro, it was co-funded by European structural funds (90\%) and loans (10\%) and it lasted 5 years (2004-2009).

The citizens' vision was that Olympion Coast would become a place providing comfort to any visitor of the area such as bathers, pedestrians or tourists. The entire area would have a large amount of colours, physical images and figures and a variety of uses. According to the designing philosophy Olympion Coast should become interesting and attractive to all citizens and tourists.

Furthermore, the project aimed at remodelling and rationalising land use of wider parts of the city under a holistic framework implementing sustainability; i.e. transportation network, connection with the city centre, car parks in central parts, rationalised use of the main landmarks of the city such as the Marina area, the old port, the medieval castle and the National Garden.

The basic targets of the study for Olympion Coast in compliance with sustainable development could be resumed to the following:

a. the creation of a public and organised beach which in combination with a pedestrians' precinct would serve not only bathers but also pedestrians;

b. the preservation of the morphology of the natural environment of the area and the shore;

c. the optical and operational connection of the shore with the surrounding environment;

d. the respect of the historical features of the area.

The connection between the road and the shore is taking place through a green ribbon, a bike street and a pedestrians' precinct, which are the result of a free design following the natural environment flow among the trees. Hence, the natural environment has been preserved, while more trees have been planted along the pedestrians' precinct. 

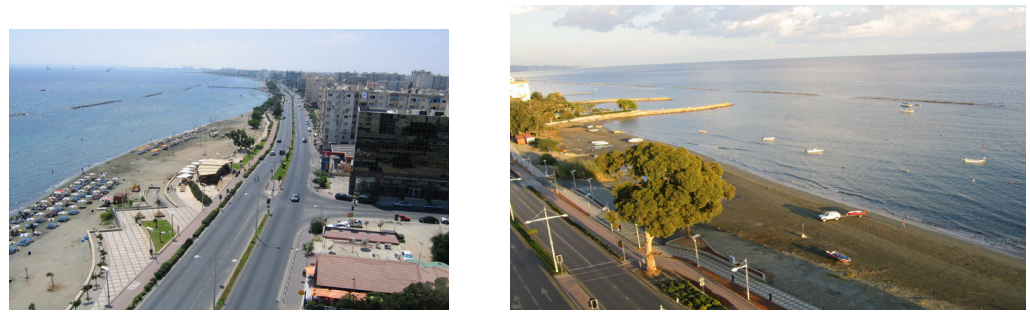

Figure 1: $\quad$ The remodelled Olympion Coast.

The main legal obstacle that needed to be overcome was the lack of the legal framework on bike streets. Therefore, before the starting date of the project, a resolution on the construction of bike streets was voted by the Cyprus parliament, and the legislation on bike streets was adopted in the local center plan of Limassol in March of 2003, so that project would begin (Georgoudis [14]).

\section{Conclusions}

In the last 30 years, the city of Limassol has been subject to a continuous urban growth with an average annual rate of $1.2 \%$. Representing currently an urban population of about 161,000 inhabitants, it has varied its weight within the Great Urban /Metropolitan Area from almost 70\% in 1982 to only 58\% today. The phenomena of disperse growth, due to the suburbanization in the surrounding satellite cities and the parallel increasing of the private vehicle park, imply the growth of mobility demand and of the displacement distances: More and longer trips are done, especially in motorised private transport. Having a look to the distribution of activities within the city of Limassol, it can be manifested the following: Whilst the population is spread out all over the city area, the economic activities, such as the employment and commerce facilities, the administrative buildings as well as the tourist accommodations, are concentrated mainly in the urban centre of the city, the Central Business District [15].

Urban renaissance of Limassol coast has completely changed the physiognomy of the city. The development of the bike street network has enhanced the environment and promoted sustainable mobility in the city because of the wide use of bikes instead of cars. Besides, Olympion Coast project has been applauded by the biggest part of the inhabitants of the city.

The remodelling of Olympion Coast was completed in 2009 and has marked the starting point of various similar projects. In the near future, among the goals of the local government is the construction of a large bike street network through the city centre ensuring both walkability and sustainable mobility. Besides, the remodeling in question has accelerated urban renaissance in the wider coastal area of the city. Thus, in 2011 another similar project has begun: the urban renaissance of the adjacent embankment area with a view to creating a multifunctional coastal park within a period of ten years. The project is being financed by European structural funds $(85 \%)$ and national funds $(25 \%)$. This 
project is related to the remodelling of Olympion Coast both geographically and functionally [16]. Moreover, both interventions mark the organic connection of the city with the sea, an intrinsic feature of the physiognomy of Limassol.

Hence, urban renaissance in Limassol contributes in promoting both sustainable mobility and sustainable compact city with respect to the traditional relation between the settlement itself and the seafront. Consequently, we could put forward the idea that the success of the above urban intervention is based on having apprehended and assessed both the present and future operational needs of a modern city in Eastern Mediterranean according to the principles of the European policy for the city. Furthermore, it has taken in consideration the history and collective memory of the inhabitants by preserving the natural landscape of the coast and showing of elements of the local cultural heritage, i.e. the old harbour and the medieval castle.

So, as a general conclusion for similar urban interventions we could stress the importance of not only quantitative but also qualitative criteria in urban renaissance so that the remodelled area proposes a vision for the future based however on local collective memory.

\section{References}

[1] Hatzopoulou, A., The influence of legal rules on built environment and the physiognomy of the city, Archailogia, 79, pp. 69-72, 2001.

[2] Aristotle, Apanta, book 2, Cactos: Athens, pp. 53, 69, 1993.

[3] The Limits to Growth, http://en.wikipedia.org/wiki/The_Limits_to_Growt

[4] The club of Rome, www.clubofrome.org

[5] European Commission, Sustainable development. Together for Tomorrow, http://ec.europa.eu/sustainable/sds2001/index_en.htm

[6] Europa, Policy areas, Environment, http://europa.eu/pol/env/index_en.htm

[7] EU News, Policy Positions \& EU Actors Online, 19 February 2006, www.SustainableMobility/EuropeanUnion/Transport.htm

[8] European Platform on Mobility Management, www.epomm.org

[9] Newman, P. \& Kenworthy, J., An International Sourcebook of Automobile Dependence in Cities 1960/1990, University Press of Colorado.

[10] Leipzig Charter on Sustainable European Cities, www.sadas-pea.gr, Leipzig Charter, (2007)

[11] History of Limassol, http://www.schools.ac.cy/lyc-ala-lim/EUhistory_ of limassol.htm

[12] History of the town of Lemesos (Limassol), www.limassolmunicipal.com. cy/history/index.html

[13] History of Cyprus, http://en.wikipedia.org/wiki/History_of_Cyprus

[14] Georgoudis, M., Sustainable mobility: a new approach in the transport sector, Master's Report NTUA: Athens 2009.

[15] SMAP, Mobility Master Plan of Limassol Executive Summary, March 2006, www.medcities.org/docs/Executive\%20Summary\%20Lemesos.pdf

[16] Limassol: the remodelling of the pier begins, www.sigmalive.com/ inbusiness/news/property/337970. 